\title{
Granulicella paludicola gen. nov., sp. nov., Granulicella pectinivorans sp. nov., Granulicella aggregans sp. nov. and Granulicella rosea sp. nov., acidophilic, polymer-degrading acidobacteria from Sphagnum peat bogs
}

\section{Correspondence \\ Svetlana N. Dedysh dedysh@mail.ru}

\author{
Timofey A. Pankratov and Svetlana N. Dedysh \\ S. N. Winogradsky Institute of Microbiology, Russian Academy of Sciences, Prospect 60-letya \\ Octyabrya 7/2, Moscow 117312, Russia
}

The phylum Acidobacteria is highly diverse and, at the time of publishing, comprises 26 distinct phylogenetic subdivisions (Barns et al., 2007). Only three of them, subdivisions 1 , 3 and 8 , have taxonomically characterized representatives. The taxa with validly published names from subdivision 1 include the genera Acidobacterium (Kishimoto et al., 1991),

\footnotetext{
Abbreviation: EPS, extracellular polymeric substance.

The GenBank/EMBL/DDBJ accession numbers for the 16S rRNA gene sequences of Granulicella aggregans TPB $6028^{\top}$, G. pectinovorans $\mathrm{TPT} 011^{\top}$, G. paludicola OB1010 ${ }^{\top}$ and G. rosea $\mathrm{TPO}^{\mathrm{O}} \mathrm{O} 14^{\top}$ are AM887756-AM887759, respectively.

Micrographs of negatively stained thin sections of vegetative TPO $1014^{\top}$ cells, and cells of strain TPB6011 ${ }^{\top}$ in 2-week-old culture, a chart showing the inhibitory effect of phosphate ions on the growth of acidobacteria and a table showing whole-cell fatty acid compositions of novel species of Granulicella gen. nov. are available with the online version of this paper.
}

Terriglobus (Eichorst et al., 2007) and Edaphobacter (Koch et al., 2008). The only described genus in subdivision 3 is Bryobacter (Kulichevskaya et al., 2010), while subdivision 8 includes the genera Holophaga (Liesack et al., 1994), Geothrix (Coates et al., 1999) and Acanthopleuribacter (Fukunaga et al., 2008).

Members of the phylum Acidobacteria inhabit a wide range of natural environments of diverse temperature, salinity and $\mathrm{pH}$. They have been detected in soils and sediments (Barns et al., 1999, 2007; Janssen, 2006; Lauber et al., 2009), hot springs (Hugenholtz et al., 1998; Barns et al., 1999; Bryant et al., 2007), acidic mining lakes (Kleinsteuber et al., 2008), water distribution systems (Martiny et al., 2005) and caves (Zimmermann et al., 2005; Meisinger et al., 2007). Recently, we reported that one-third of all bacterial $16 \mathrm{~S}$ rRNA gene sequences retrieved from acidic Sphagnum peat were grouped with the Acidobacteria (Dedysh et al., 2006). 
Our further cultivation efforts resulted in the isolation of several strains of peat-inhabiting acidobacteria in pure cultures (Pankratov et al., 2008). Most of these isolates belonged to subdivision 1 of the Acidobacteria and represented strictly aerobic, acidophilic organisms that were able to hydrolyse a number of polysaccharides. In this paper, we provide a detailed characterization of five of these isolates, strains $\mathrm{TPB}^{2} 011^{\mathrm{T}}, \mathrm{TPO} 1014^{\mathrm{T}}, \mathrm{TPB}^{2} 028^{\mathrm{T}}$, $\mathrm{OB} 1010^{\mathrm{T}}$ and LCBR1, and propose a novel genus, containing four novel species of these bacteria.

Strains $\mathrm{TPO} 1014^{\mathrm{T}}$ and $\mathrm{OB} 1010^{\mathrm{T}}$ were isolated from a peat sample ( $\mathrm{pH} 4.2)$ collected from the upper oxic layer, 0$10 \mathrm{~cm}$ below the surface, of the bog Obukhovskoe, Yaroslavl region, European North Russia $\left(58^{\circ} 14^{\prime}\right.$ N $38^{\circ} 12^{\prime}$ E). Strains TPB6011 ${ }^{\mathrm{T}}$ and $\mathrm{TPB}^{2} 028^{\mathrm{T}}$ were obtained from peat soil ( $\mathrm{pH} 4.0$ ) sampled at a depth of $10-20 \mathrm{~cm}$ of the Sphagnum peat bog Bakchar, Tomsk region, West Siberia $\left(56^{\circ} 51^{\prime} \mathrm{N} 82^{\circ}\right.$ $50^{\prime}$ E). Strain LCBR1 was isolated from the thalli of lichen species of the genus Cladonia collected from the Sphagnum peat bog Bakchar. Isolation procedures and culture conditions were used as described by Pankratov et al. (2008). The isolation was performed using basal MM1 medium containing (per litre distilled water): $\mathrm{MgSO}_{4} .7 \mathrm{H}_{2} \mathrm{O}(0.04 \mathrm{~g})$; $\mathrm{CaCl}_{2} .2 \mathrm{H}_{2} \mathrm{O}(0.02 \mathrm{~g})$; and yeast extract $(0.05 \mathrm{~g})$. Dialysed humic acid (prepared as described by Pansu \& Gautheyrou, 2006) (1 ml); galacturonic acid sodium salt, $30 \mathrm{mg}$, glucuronic acid, $30 \mathrm{mg}$, and homoserine, $10 \mathrm{mg}$ were included in the MM1 medium as additional components. Xylan or pectin $(0.05 \%, \mathrm{w} / \mathrm{v})$ were used as carbon sources. The solidifying agent used for the medium preparation was Gel-Gro (ICN Biomedicals). To avoid increasing ionic strength, $\mathrm{pH}$ was adjusted to $4.0-5.0$ with $20-50 \mathrm{mg}$ alginic acid $\mathrm{l}^{-1}$. Once established as pure cultures, the isolates were maintained on MM1 agar medium ( $\mathrm{pH} 4.6-5.0)$ with fructose and were subcultured at 4-week intervals. Terriglobus roseus DSM $18391^{\mathrm{T}}$ and Edaphobacter aggregans DSM $19364^{\mathrm{T}}$ were used as reference strains in our study and were maintained on media 830 and 1135 as recommended by the Deutsche Sammlung von Mikroorganismen und Zellkulturen (DSMZ, Braunschweig, Germany).

Cell morphology was examined using cultures grown both in liquid and on agar MM1 media. For the preparation of ultrathin sections, cells harvested in the exponential growth stage were pre-fixed with $1.5 \%(\mathrm{w} / \mathrm{v})$ glutaraldehyde in $0.05 \mathrm{M}$ cacodylate buffer ( $\mathrm{pH}$ 6.5) for $1 \mathrm{~h}$ at $4{ }^{\circ} \mathrm{C}$ and then fixed in $1 \%(\mathrm{w} / \mathrm{v})$ osmium tetroxide in the same buffer for $4 \mathrm{~h}$ at $20^{\circ} \mathrm{C}$. Capsule substances were contrasted by glutaraldehyde/osmium fixation in the presence of ruthenium red (Luft, 1964). The samples were dehydrated in an ethanol series and embedded in Spurr's epoxy resin. Thin sections were cut on an LKB-4800 microtome, mounted on copper grids covered with Formvar film, contrasted with uranyl acetate (3\%, in $70 \%$ ethanol) for $30 \mathrm{~min}$ and then stained with lead citrate (Reynolds, 1963) at $20{ }^{\circ} \mathrm{C}$ for 4 $5 \mathrm{~min}$. The specimens were examined with a JEM-100C (JEOL) electron microscope at $80 \mathrm{kV}$ accelerating voltage. Absorption spectra of methanol extracts of cells of novel isolates were determined between 250 and $1000 \mathrm{~nm}$ using a SPh-56 spectrophotometer (Lomo-Spectrum).

Growth of the novel strains was examined using batch cultures grown in liquid MM1 medium with fructose at 2$37^{\circ} \mathrm{C}$, pH $2-9$ and in $\mathrm{NaCl}, \mathrm{KCl}$ and $\mathrm{K}_{2} \mathrm{HPO}_{4}$ concentrations of $0.01-7.0 \%(\mathrm{w} / \mathrm{v}) . \mathrm{OD}_{600}$ was measured in an Eppendorf BioPhotometer at 2-day intervals for 3 weeks. To account for cases of non-homogeneous growth, measurement of $\mathrm{CO}_{2}$ production rates by infrared gas spectroscopy with a thermal conductivity detector was used in place of $\mathrm{OD}_{600}$. The range of potential growth substrates of the novel strains was examined by replacing fructose in MM1 medium with alternative carbon sources. The ability to degrade different biopolymers was examined by measuring the rate of $\mathrm{CO}_{2}$ production of cultures grown in tightly closed $500 \mathrm{ml}$ serum bottles containing $100 \mathrm{ml}$ liquid MM1 medium with $0.05 \%(\mathrm{w} / \mathrm{v})$ of the corresponding polymer substrate for 3 weeks at $20{ }^{\circ} \mathrm{C}$. Control incubations were run in parallel under the same conditions but without substrate. Isolates were also tested for their ability to grow anaerobically, determining the fermentation of glucose or fructose, or by anaerobic respiration with nitrate $(1 \mathrm{mM})$ as the electron acceptor and glucose or fructose $(0.05 \%, \mathrm{w} / \mathrm{v})$ as the sole carbon and energy source. These tests were performed in tightly closed $160 \mathrm{ml}$ serum flasks containing $30 \mathrm{ml}$ liquid MM1 medium. Before autoclaving, the medium and the headspace of the flasks were flushed for $10 \mathrm{~min}$ with a mixture of $\mathrm{CO}_{2}(7 \%)$ and $\mathrm{N}_{2}(93 \%)$ to replace the air.

Enzyme activity profiles, urease hydrolysis, indole production and the Hugh-Leifson test were analysed with API 20NE and API ZYM kits (bioMérieux). Catalase and oxidase tests were carried out by standard methods (Gerhardt et al., 1981). Antibiotic susceptibilities were determined on MM1 agar plates using discs (Oxoid) containing the following antibiotics ( $\mu \mathrm{g})$ : ampicillin (10), gentamicin (10), kanamycin (30), neomycin (10), novobiocin (30), streptomycin (10), chloramphenicol (30) and lincomycin (10).

Cell biomass for cellular fatty acid and isoprenoid quinone analyses and for DNA extraction was obtained from batch cultures grown in liquid MM1 medium at $24{ }^{\circ} \mathrm{C}$ for 1 week. Fatty acid profiles were analysed by the DSMZ Identification Service as described by Kämpfer \& Kroppenstedt (1996). Identification of isoprenoid quinones was performed as reported by Pankratov et al. (2007). DNA base composition of each strain was determined by thermal denaturation using a Cary-100 UV-Vis spectrophotometer (Varian) at a heating rate of $0.5{ }^{\circ} \mathrm{C} \mathrm{min}^{-1}$. The DNA $\mathrm{G}+\mathrm{C}$ contents were calculated according to Owen et al. (1969) using Escherichia coli $\mathrm{K}-12(\mathrm{G}+\mathrm{C} 51.7 \mathrm{~mol} \%)$ as a standard. DNA-DNA hybridization experiments were performed as described by De Ley et al. (1970). The $16 \mathrm{~S}$ rRNA gene sequences of strains $\mathrm{TPO} 014^{\mathrm{T}}, \mathrm{TPB} 011^{\mathrm{T}}, \mathrm{OB} 1010^{\mathrm{T}}$ and TPB6028 ${ }^{\mathrm{T}}$ were determined previously (Pankratov et al., 2008), whereas the corresponding gene sequence of strain LCBR1 was analysed in this study. Phylogenetic analyses were carried out using the ARB program package (Ludwig et al., 2004). Trees were 
constructed using distance-based (neighbour-joining), maximum-likelihood (DNAML) and maximum-parsimony methods. The significance levels of interior branch points obtained in neighbour-joining analyses were determined by bootstrap analysis (1000 data resamplings) using the PHYLIP program (Felsenstein, 1989).

All five strains formed convex, irregularly circular, semitransparent or opaque colonies when grown on solid media made with Gel-Gro. Strains TPB6011 ${ }^{\mathrm{T}}$ and TPB6028 ${ }^{\mathrm{T}}$ produced slimy colonies, colonies of strains $\mathrm{TPO} 1010^{\mathrm{T}}$ and LCBR1 had a creamy consistency, while strain TPO1014 produced solid, rubbery colonies that could be peeled from the agar surface. At the stage of isolation, colonies of strains TPO1014 ${ }^{\mathrm{T}}, \mathrm{OB} 1010^{\mathrm{T}}$, LCBR1 and TPB6028 ${ }^{\mathrm{T}}$ did not exceed $0.5 \mathrm{~mm}$ in diameter; after a series of further transfers on laboratory media under optimal conditions, these isolates began to form significantly larger colonies of up to $3 \mathrm{~mm}$ in diameter. The colonies of strain TPB6011 were larger, reaching $3-5 \mathrm{~mm}$ in diameter. Colonies were pale pink-red in strains TPB6011 ${ }^{\mathrm{T}}, \mathrm{OB} 1010^{\mathrm{T}}$ and LCBR1 and light pink to pink in strains TPO1014 ${ }^{\mathrm{T}}$ and $\mathrm{TPB}^{\mathrm{T}} 628^{\mathrm{T}}$. The main absorption maxima detected in methanol extracts of the novel isolates were at 475, 509 and $540 \mathrm{~nm}$, which are values typical of carotenoids and are most similar to those of spirilloxanthin. These absorption peaks were highly similar to the peaks of the carotenoids in Terriglobus roseus (Eichorst et al., 2007). In liquid media, strains $\mathrm{TPB}^{2} 011^{\mathrm{T}}, \mathrm{OB} 1010^{\mathrm{T}}$ and LCBR1 grew homogeneously, while strains $\mathrm{TPO} 1014^{\mathrm{T}}$ and $\mathrm{TPB} 6028^{\mathrm{T}}$ displayed flocculent growth.

Cells of the novel isolates were Gram-negative, non-sporeforming, non-motile rods that divided by binary fission and occurred singly or in pairs (Supplementary Fig. S1a-d, available in IJSEM Online). Cultures of strains TPB6011 and $\mathrm{TPB} 6028^{\mathrm{T}}$ also contained short chains of three to five cells. Cells of the novel isolates varied with regard to their length and width (Table 1). Cells of strains $\mathrm{OB} 1010^{\mathrm{T}}$ and LCBR1 were shorter than those of strains TPO1014, TPB $6011^{\mathrm{T}}$ and TPB6028 $8^{\mathrm{T}}$. However, in general, cells of the novel isolates were significantly longer than cells of Terriglobus roseus DSM $18391^{\mathrm{T}}$ and Edaphobacter aggregans DSM $19364^{\mathrm{T}}$ when grown under the same conditions (Supplementary Fig. S1e-f). Production of an amorphous extracellular polymeric substance (EPS) was characteristic of all five novel isolates but was more strongly pronounced in strains TPB6011 $1^{\mathrm{T}}$, TPO $1014^{\mathrm{T}}$ and TPB6028 ${ }^{\mathrm{T}}$. Staining of this EPS with Alcian blue (Scott et al., 1964) and ruthenium red (Luft, 1964) indicated that it was a polysaccharide-like substance (Supplementary Fig. S2).

Electron microscopy revealed a cell-wall structure typical of Gram-negative bacteria. The cytoplasmic membrane, peptidoglycan layer and outer membrane were evident in ultrathin sections (Fig. 1a). We also revealed the presence of numerous outer-membrane vesicles, ranging in size from 40 to $100 \mathrm{~nm}$ (Fig. 1b). Formation of these vesicles was most evident in strain TPO1014 ${ }^{\mathrm{T}}$. Interestingly, the analysis of three recently sequenced genomes of acidobacteria suggests they are able to synthesize a large number of high-molecular-mass excreted proteins (Ward et al., 2009).

Old cultures of the novel isolates contained numerous elongated cells (up to $50 \mu \mathrm{m}$ ) as well as spherical bodies of varying sizes $(0.5-3 \mu \mathrm{m})$ (Supplementary Figs S1a, b and S3a-c). These spherical cells did not show a peptidoglycan layer and had often lost most of their cytoplasm (Supplementary Fig. S3d-e). However, after transfer to fresh medium, some of these cells were able to grow out again into rods. Morphologically and structurally similar cells have been observed in several representatives of the order Cytophagales when starved during growth (Reichardt \& Morita, 1982; Reichenbach, 2006), which suggests that the morphologies observed are examples of survival forms in nature when low temperature and nutrient deprivation conditions exist (Reichardt \& Morita, 1982).

All five novel isolates were strictly aerobic and had a requirement for the presence of growth factors (50 mg yeast extract or Casamino acids $1^{-1}$ ) in the cultivation medium. Thus, utilization of a given carbon compound was assumed to have occurred when growth was distinctly improved by its presence, compared with basal MM1 medium alone. The carbon compounds tested and their effects on growth are given in the four species descriptions and are shown in Table 1. Most sugars were preferred as growth substrates. Strain TPO $1014^{\mathrm{T}}$ differed from the other strains by being able to utilize only a limited number of growth substrates. All five isolates possessed hydrolytic capabilities and were able to degrade pectin, laminarin, xylan, lichenan and starch, but not cellulose, CM-cellulose, chitin, chitosan, fucoidan, sodium alginate, chondroitin sulphate or pullulan. Hydrolytic capability was most strongly pronounced in strain $\mathrm{TPB} 6011^{\mathrm{T}}$, and pectin was the preferred polymeric substrate. For comparison, Terriglobus roseus DSM $18391^{\mathrm{T}}$ and Edaphobacter aggregans DSM $19364^{\mathrm{T}}$ were tested along with our isolates. Terriglobus roseus DSM $18391^{\mathrm{T}}$ was able to degrade pectin and starch but showed only poor growth on xylan and laminarin, and was unable to degrade lichenan. Edaphobacter aggregans DSM $19364^{\mathrm{T}}$ showed good growth on laminarin and lichenan but grew poorly on xylan and starch and was unable to degrade pectin.

API ZYM tests revealed the strain with the largest number of enzyme activities was strain $\mathrm{TPB} 6011^{\mathrm{T}}$, which also displayed the strongest hydrolytic capabilities. This isolate differed from the other four by the presence of trypsin and urease (Table 1). The smallest number of enzyme activities was detected in strain $\mathrm{TPO} 1014^{\mathrm{T}}$, which utilized only a limited number of growth substrates. All five isolates were sensitive to novobiocin and were resistant to chloramphenicol, gentamicin, streptomycin and neomycin. Strains TPB6011 ${ }^{\mathrm{T}}, \mathrm{OB} 1010^{\mathrm{T}}$ and LCBR1 differed from strains $\mathrm{TPO} 1014^{\mathrm{T}}$ and $\mathrm{TPB} 6028^{\mathrm{T}}$ by being susceptible to lincomycin (Table 1).

The novel isolates grew at $\mathrm{pH} 3.0-7.5$, with optima between $\mathrm{pH} 3.8$ and 4.5. The temperature range for growth 
Table 1. Phenotypic characteristics of five novel strains of acidobacteria isolated from Sphagnum peat bogs

1, Granulicella paludicola $\mathrm{OB} 1010^{\mathrm{T}}$; 2, Granulicella paludicola LCBR1; 3, Granulicella pectinivorans $\mathrm{TPB} 6011^{\mathrm{T}} ; 4$, Granulicella rosea $\mathrm{TPO} 1014^{\mathrm{T}}$; 5, Granulicella aggregans $\mathrm{TPB}^{2} 028^{\mathrm{T}}$. All strains utilized D-glucose, D-fructose, sodium galacturonate, xylan, pectin, laminarin, lichenan and starch. Substrates tested but not utilized by all of the strains: D-arabinose, D-sorbose, D-fucose, butyrate, oxalate, propionate, formate, fumarate, sodium hexanoate, citrate, valerate, adonitol, ethanol, methanol, pullulan, fucoidan, CM-cellulose, cellulose, chitin and chitosan. All strains were positive for catalase, did not reduce nitrates to nitrites, did not produce indole from tryptophan, and did not ferment glucose. All strains were sensitive to novobiocin and were resistant to chloramphenicol, gentamicin, streptomycin and neomycin. w, Weak activity.

\begin{tabular}{|c|c|c|c|c|c|}
\hline Characteristic & 1 & 2 & 3 & 4 & 5 \\
\hline Cell length $(\mu \mathrm{m})$ & $1.5-3.5$ & $1.5-3.0$ & $1.5-15$ & $1.5-9.0$ & $1.5-10$ \\
\hline Cell width $(\mu \mathrm{m})$ & $0.4-0.6$ & $0.4-0.6$ & $0.8-1.0$ & $0.5-1.0$ & $0.8-1.5$ \\
\hline Homogeneous growth & + & + & + & - & - \\
\hline Colony colour & Red & Red & Red & Pink & Pink \\
\hline \multicolumn{6}{|l|}{ Utilization of sugars } \\
\hline D-Galactose & + & + & + & - & + \\
\hline Lactose & + & + & - & - & - \\
\hline Lactulose & + & + & - & - & + \\
\hline Leucrose & + & + & - & - & + \\
\hline Maltose & + & + & - & + & + \\
\hline D-Mannose & + & + & + & - & + \\
\hline Melezitose & + & + & - & - & - \\
\hline Melibiose & + & + & + & - & - \\
\hline Raffinose & + & + & - & - & - \\
\hline D-Rhamnose & + & + & - & - & + \\
\hline D-Ribose & - & - & - & - & + \\
\hline Salicin & + & + & - & + & + \\
\hline Sucrose & + & + & + & - & + \\
\hline Trehalose & - & - & + & - & - \\
\hline Cellobiose & + & + & + & - & - \\
\hline D-Xylose & + & - & + & + & + \\
\hline $\begin{array}{l}N \text {-Acetyl-D- } \\
\text { glucosamine }\end{array}$ & + & + & + & - & + \\
\hline \multicolumn{6}{|l|}{ Utilization of acids } \\
\hline Acetate & - & - & + & - & - \\
\hline Gluconate & $\mathrm{w}$ & + & + & - & + \\
\hline Glucuronate & - & + & - & + & + \\
\hline Lactate & - & - & + & - & - \\
\hline Malate & - & - & - & + & + \\
\hline Pyruvate & - & - & - & + & + \\
\hline Succinate & - & - & + & - & - \\
\hline \multicolumn{6}{|l|}{$\begin{array}{l}\text { Utilization of } \\
\text { polyalcohols }\end{array}$} \\
\hline Arbutin & - & + & - & - & + \\
\hline Inulin & + & - & + & - & - \\
\hline Mannitol & - & - & + & - & + \\
\hline myo-Inositol & - & + & + & - & + \\
\hline Sorbitol & - & - & - & - & + \\
\hline Dulcitol & - & - & - & - & + \\
\hline \multicolumn{6}{|l|}{ Susceptibility to: } \\
\hline Ampicillin & - & - & - & + & - \\
\hline
\end{tabular}

Table 1. cont.

\begin{tabular}{|lccccc|}
\hline Characteristic & $\mathbf{1}$ & $\mathbf{2}$ & $\mathbf{3}$ & $\mathbf{4}$ & $\mathbf{5}$ \\
\hline Kanamycin & - & - & + & + & - \\
Lincomycin & + & + & + & - & - \\
Oxidase & + & + & + & - & - \\
Enzyme activities & & & & & \\
Esterase (C4) & + & - & w & - & + \\
Esterase lipase (C8) & - & - & + & + & + \\
Valine arylamidase & + & + & + & - & + \\
$\alpha$-Chymotrypsin & - & + & + & - & + \\
$\alpha$-Galactosidase & + & + & + & - & - \\
$\alpha$-Glucosidase & + & + & + & - & + \\
$\quad N-$-Acetyl- $\beta$ - & + & + & + & - & + \\
glucosaminidase & & & & & \\
Trypsin & - & - & + & - & - \\
Urease & - & - & + & - & - \\
DNA G+C content & 57.4 & 57.3 & 59.1 & 58.3 & 59.3 \\
(mol\%) & & & & & \\
\hline
\end{tabular}

was $2-33{ }^{\circ} \mathrm{C}$, with optima between 15 and $22{ }^{\circ} \mathrm{C}$. Under optimal conditions, the growth rate of these bacteria was in the range $0.05-0.10 \mathrm{~h}^{-1}$. Strains $\mathrm{OB} 1010^{\mathrm{T}}$, LCBR1, $\mathrm{TPB} 6011^{\mathrm{T}}$, $\mathrm{TPO} 1014^{\mathrm{T}}$ and $\mathrm{TPB}^{2} 028^{\mathrm{T}}$ were relatively resistant to $\mathrm{NaCl}$. They grew well in media at $\mathrm{NaCl}$ concentrations up to $3.5 \%(\mathrm{w} / \mathrm{v})$; complete inhibition of growth was observed at $5 \%(\mathrm{w} / \mathrm{v}) \mathrm{NaCl}$ and above. Growth

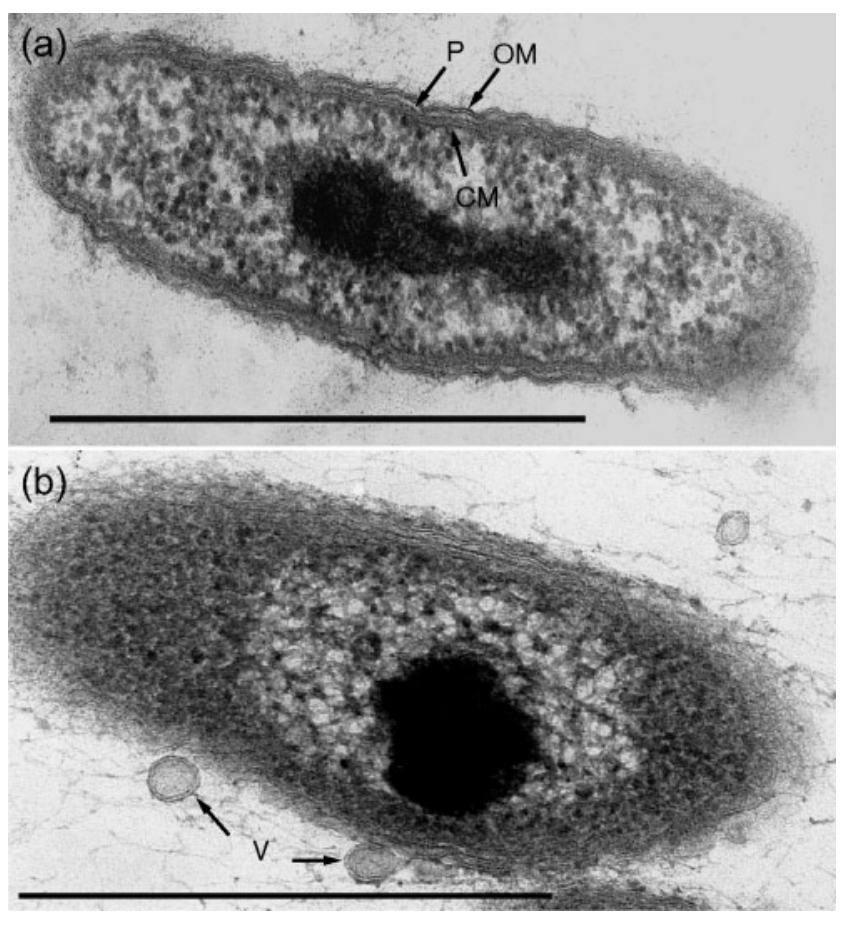

Fig. 1. Electron micrographs of ultrathin sections of vegetative cells of strain $\operatorname{TPB} 011^{\top}$ (a) and TPO1014 ${ }^{\top}$ (b). OM, Outer membrane; CM, cytoplasmic membrane; $\mathrm{P}$, peptidoglycan layer; $\mathrm{V}$, outer membrane vesicles. Bars, $1.0 \mu \mathrm{m}$. 
inhibition of 20 and $80 \%$ was observed in the presence of $\mathrm{KH}_{2} \mathrm{PO}_{4}$ at concentrations of 0.7 and $6.7 \mathrm{mM}$, respectively, whereas no inhibition was detected in the presence of $\mathrm{KCl}$ within the same range of concentrations (Supplementary Fig. S4). Our results indicate that phosphate ions can inhibit growth of some acidobacteria.

The five novel isolates contained MK- 8 as the predominant menaquinone. The major fatty acids of strains $\mathrm{OB} 1010^{\mathrm{T}}$, LCBR1, TPB6011 ${ }^{\mathrm{T}}, \mathrm{TPO} 1014^{\mathrm{T}}$ and $\mathrm{TPB} 6028^{\mathrm{T}}$ were iso$\mathrm{C}_{15: 0}, \mathrm{C}_{16: 0}$ and summed feature $3\left(\mathrm{C}_{16: 1} \omega 7 \mathrm{c} /\right.$ iso- $\mathrm{C}_{15: 0} 2$ $\mathrm{OH})\left(\right.$ Table 2). Strains OB1010 ${ }^{\mathrm{T}}$ and LCBR1 also contained iso- $\mathrm{C}_{13: 0}$ in substantial amounts $(8.6-9.7 \%)$. These cellular fatty acid profiles had significant similarity to those of the subdivision 1 acidobacteria Terriglobus roseus and Edaphobacter modestus (Eichorst et al., 2007; Koch et al., 2008) (Supplementary Table S1).

Comparative 16S rRNA gene sequence analysis showed that strains $\mathrm{OB} 1010^{\mathrm{T}}$, LCBR1, TPB6011 ${ }^{\mathrm{T}}$, TPO1014 ${ }^{\mathrm{T}}$ and $\mathrm{TPB}^{2} 28^{\mathrm{T}}$ show between 95.3 and $98.9 \%$ similarity to each other and belong to subdivision 1 of the phylum

Table 2. Whole-cell fatty acid compositions (\%) of five novel strains of acidobacteria from Sphagnum peat bogs

1, Granulicella paludicola $\mathrm{OB} 1010^{\mathrm{T}} ; 2$, Granulicella paludicola LCBR1; 3, Granulicella pectinivorans $\mathrm{TPB}^{2} 011^{\mathrm{T}} ; 4$, Granulicella rosea $\mathrm{TPO} 014^{\mathrm{T}} ; 5$, Granulicella aggregans $\mathrm{TPB}^{2} 028^{\mathrm{T}}$. Major fatty acids are shown in bold. -, Not detected.

\begin{tabular}{|c|c|c|c|c|c|}
\hline Fatty acid & 1 & 2 & 3 & 4 & 5 \\
\hline \multicolumn{6}{|l|}{ Saturated } \\
\hline $\mathrm{C}_{14: 0}$ & 1.3 & 1.2 & 2.5 & 5.2 & 1.7 \\
\hline $\mathrm{C}_{15: 0}$ & 0.6 & 1.6 & 0.4 & - & - \\
\hline $\mathrm{C}_{16: 0}$ & 12.5 & 10.6 & 6.0 & 7.3 & 10.7 \\
\hline $\mathrm{C}_{17: 0}$ & 0.9 & 0.6 & 0.5 & 0.3 & 0.7 \\
\hline $\mathrm{C}_{18: 0}$ & 0.5 & 0.4 & 0.3 & 0.3 & 1.1 \\
\hline $\mathrm{C}_{20: 0}$ & 0.4 & 0.9 & 0.3 & 0.9 & 1.7 \\
\hline \multicolumn{6}{|l|}{ Unsaturated } \\
\hline $\mathrm{C}_{14: 1} \omega 5 c$ & 0.3 & 0.1 & 3.4 & 2.9 & 0.6 \\
\hline $\mathrm{C}_{15: 1} \omega 6 c$ & 0.5 & - & 1.5 & 1.2 & 0.8 \\
\hline $\mathrm{C}_{16: 1} \omega 5 c$ & - & - & 0.1 & - & - \\
\hline $\mathrm{C}_{17: 1} \omega 8 c$ & 0.1 & - & 0.1 & - & - \\
\hline $\mathrm{C}_{18: 1} \omega 7 c$ & 0.2 & 0.2 & 0.2 & - & - \\
\hline \multicolumn{6}{|l|}{ Methyl-branched } \\
\hline iso- $\mathrm{C}_{11: 0}$ & 0.2 & 0.5 & 0.1 & - & 0.2 \\
\hline iso- $\mathrm{C}_{13: 0}$ & 9.7 & 8.6 & 0.4 & 0.1 & 0.4 \\
\hline iso- $\mathrm{C}_{15: 0}$ & 40.8 & 46.8 & 52.8 & 59.9 & 35.5 \\
\hline anteiso- $\mathrm{C}_{15: 0}$ & 1.3 & 0.9 & 0.2 & 0.2 & - \\
\hline iso- $\mathrm{C}_{17: 1} \omega 9 c$ & 0.4 & 0.4 & 0.2 & - & 1.1 \\
\hline iso- $\mathrm{C}_{17: 0}$ & 2.3 & 3.6 & 1.5 & 0.6 & 2.8 \\
\hline anteiso- $\mathrm{C}_{17: 0}$ & 0.6 & 0.6 & 1.0 & 0.3 & 0.5 \\
\hline \multicolumn{6}{|l|}{ Hydroxy } \\
\hline $\mathrm{C}_{12: 0} 3-\mathrm{OH}$ & 0.1 & - & 0.2 & - & - \\
\hline iso- $\mathrm{C}_{15: 0} 3-\mathrm{OH}$ & - & 1.2 & 0.1 & - & - \\
\hline \multicolumn{6}{|l|}{ Summed feature } \\
\hline $\mathrm{C}_{16: 1} \omega 7 c /$ iso- $\mathrm{C}_{15: 0} 2-\mathrm{OH}$ & 26.8 & 12.7 & 27.7 & 20.7 & 42.4 \\
\hline
\end{tabular}

Acidobacteria (Fig. 2). The closest described relatives of these novel isolates are members of the genera Terriglobus (94.6-95.8\% 16S rRNA gene sequence similarity) and Edaphobacter (94.2-95.4\%). Among taxonomically uncharacterized organisms, the highest sequence similarities (97.9-98.2\%) were to the soil isolate KBS89, which was described by Eichorst et al. (2007) but not included in the genus Terriglobus. Independently of the algorithms used for the phylogenetic tree construction, the five novel isolates from Sphagnum peat and the soil isolate KBS89 formed a common cluster, which was separate from the clusters defined by members of the genera Terriglobus and Edaphobacter (Fig. 2).

Despite the clear preference of isolate KBS89 for growth conditions of low $\mathrm{pH}(\leqslant 5.0)$, and its close phylogenetic relationship to strains $\mathrm{OB} 1010^{\mathrm{T}}$, LCBR1, TPB $6011^{\mathrm{T}}$, $\mathrm{TPO} 1014^{\mathrm{T}}$ and $\mathrm{TPB} 6028^{\mathrm{T}}$, this soil isolate differed from the peat-inhabiting isolates by the absence of pigment and catalase activity, as well as by the inability to grow at $4{ }^{\circ} \mathrm{C}$.

The DNA G + C content of strains OB1010 ${ }^{\mathrm{T}}$, LCBR 1 , $\mathrm{TPB}^{2} 011^{\mathrm{T}}, \mathrm{TPO} 1014^{\mathrm{T}}$ and $\mathrm{TPB}^{2} 028^{\mathrm{T}}$ ranged from 57.3 to $59.3 \mathrm{~mol} \%$. Only two of these isolates, strains OB $1010^{\mathrm{T}}$ and LCBR1, were highly similar to each other with regard to their cell size and morphology, phenotypic characteristics and DNA $\mathrm{G}+\mathrm{C}$ content (Table 1). In contrast to other strains, they also contained substantial amounts (8.6$9.7 \%$ ) of iso- $\mathrm{C}_{13: 0}$ (Table 2). In comparative 16S rRNA gene sequence analyses, these strains always clustered together, independently of the algorithm used for phylogenetic tree construction (Fig. 2). This evidence allows us to conclude that strains $\mathrm{OB} 1010^{\mathrm{T}}$ and LCBR1 represent the same species. Other isolates displayed significant differences from each other with respect to cell morphology and phenotypic characteristics (Supplementary Fig. S1 and Table 1), which suggested that they may represent different species. This was further confirmed by the results of DNADNA hybridization studies, which revealed relatively low (9-20\%) DNA-DNA hybridization values among strains OB1010 ${ }^{\mathrm{T}}, \mathrm{TPB} 611^{\mathrm{T}}, \mathrm{TPO} 1014^{\mathrm{T}}$ and $\mathrm{TPB}^{2} 028^{\mathrm{T}}$.

In summary, our novel isolates from Sphagnum peat bogs formed a coherent phylogenetic cluster, which was separate from the clusters defined by the genera Terriglobus, Edaphobacter and Acidobacterium (Fig. 2) and possessed a number of characteristics that clearly distinguished them from all earlier described members of subdivision 1 of the phylum Acidobacteria (Table 3). Cells of the novel isolates were longer than those of members of the genera Terriglobus, Edaphobacter and Acidobacterium, were more tolerant to low temperatures and less sensitive to $\mathrm{NaCl}$. A pink colony pigmentation differentiated strains $\mathrm{OB} 1010^{\mathrm{T}}$, LCBR1, TPB6011 ${ }^{\mathrm{T}}$, TPB6028 $8^{\mathrm{T}}$ and $\mathrm{TPO}^{\mathrm{T}} 1014^{\mathrm{T}}$ from members of the genera Edaphobacter and Acidobacterium, absence of motility distinguished them from members of the genus Acidobacterium and the ability to grow at below $\mathrm{pH} 4$ distinguished them from members of the genera Terriglobus and Edaphobacter. The hydrolytic capabilities of 


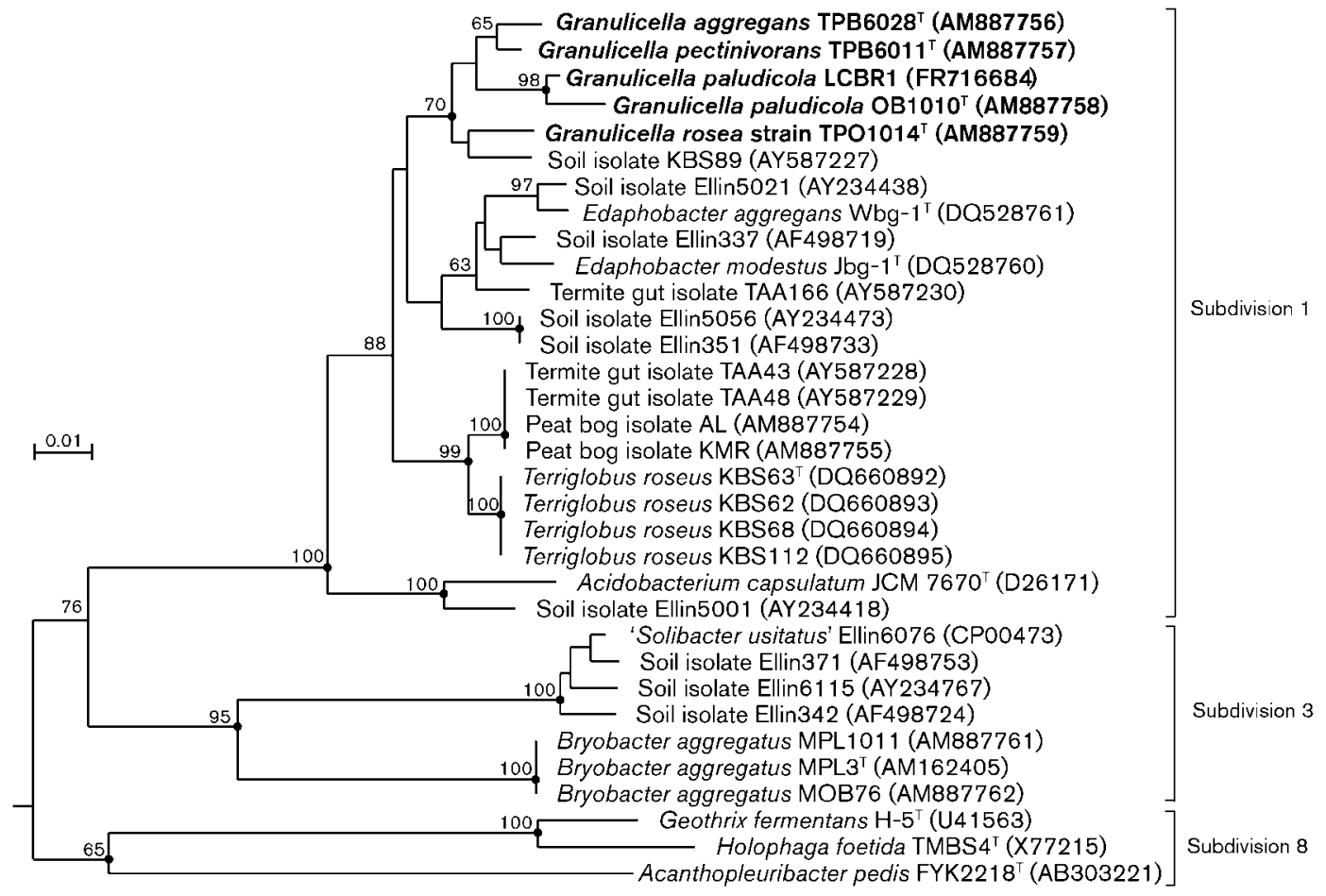

Fig. 2. $16 \mathrm{~S}$ rRNA gene-based neighbour-joining tree (Jukes-Cantor correction) showing the phylogenetic relationship of

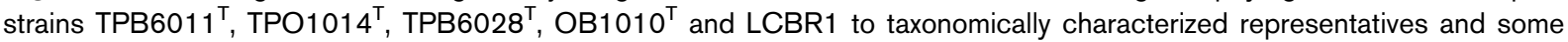
non-described members of the phylum Acidobacteria. Bootstrap values (1000 data resamplings) $>50 \%$ are shown. Filled circles indicate that the corresponding nodes were also recovered in the maximum-likelihood and maximum-parsimony trees. Six members of the phylum Planctomycetes, Isosphaera pallida strain 563 (AJ231193), Gemmata obscuriglobus strain UQM $2246^{\top}$ (X54522), Planctomyces brasilensis strain DSM 5305 ${ }^{\top}$ (AJ231190), Planctomyces maris strain DSM 8797 (AJ231184), Schlesneria paludicola strain MPL $^{\top}$ (AM162407) and Singulisphaera acidiphila ATCC BAA-1392 ${ }^{\top}$ (AM850678), were used as an outgroup (not shown). Bar, 0.01 substitutions per nucleotide position.

the peat-inhabiting bacteria were much more pronounced than in members of the genera Terriglobus and Edaphobacter. Therefore, we propose a novel genus of acidophilic, polymer-degrading bacteria, Granulicella gen. nov., containing four novel species, Granulicella paludicola sp. nov. (strains $\mathrm{OB} 1010^{\mathrm{T}}$ and LCBR1), Granulicella rosea sp. nov. $\left(\mathrm{TPO} 014^{\mathrm{T}}\right)$, Granulicella pectinivorans sp. nov. $\left(\mathrm{TPB} 6011^{\mathrm{T}}\right.$ ) and Granulicella aggregans sp. nov. (TPB6028 ${ }^{\mathrm{T}}$ ).

\section{Description of Granulicella gen. nov.}

Granulicella (Gra.nu.li.cel'la L. neut. $\mathrm{n}$ granulum a small grain; L. fem. n. cella a storeroom, chamber and, in biology, a cell; N.L. fem. n. Granulicella a grain-like cell).

Gram-negative, non-spore-forming, non-motile rods that occur singly, in pairs or in short chains. Reproduce by binary fission. Produce amorphous extracellular polysaccharide-like substances. Old cultures contain globular starvation forms. Colony colour varies from pale-pink to red. Pigments are carotenoids. Oxidase-variable and catalase-positive. Strictly aerobic chemo-organotrophs. Sugars are the preferred growth substrates. Capable of hydrolysing several polysaccharides but not cellulose or chitin. Acidophilic and mesophilic. Do not produce $\mathrm{H}_{2} \mathrm{~S}$ from thiosulfate or indole from tryptophan. $\mathrm{NaCl}$ inhibits growth at concentrations above $3.5 \%(\mathrm{w} / \mathrm{v})$. Major fatty acids are iso- $\mathrm{C}_{15: 0}, \mathrm{C}_{16: 0}$ and summed feature $3\left(\mathrm{C}_{16: 1} \omega 7 \mathrm{cl}\right.$ iso- $\left.\mathrm{C}_{15: 0} 2-\mathrm{OH}\right)$. The predominant menaquinone is MK-8. The DNA G + C content is $57.3-59.3 \mathrm{~mol} \%$. Strains have been isolated from acidic wetlands, specifically Sphagnum peat bogs. The type species is Granulicella paludicola.

\section{Description of Granulicella paludicola sp. nov.}

Granulicella paludicola (pa.lu.di'co.la. L. n. palus, -udis swamp, bog; L. suff. - cola derived from incola inhabitant, dweller; N.L. n. paludicola an inhabitant of bogs).

The description is as for the genus with the following additional traits. Cells are $0.4-0.6 \times 1.5-3.5 \mu \mathrm{m}$. Colony colour varies from pink to red. Growth is homogeneous in liquid medium. Able to utilize the following carbon sources $(0.05 \%, \mathrm{w} / \mathrm{v})$ : D-glucose, D-fructose, cellobiose, D-galactose, lactose, lactulose, leucrose, maltose, D-mannose, melibiose, melezitose, D-rhamnose, raffinose, sucrose, salicin, $N$-acetylD-glucosamine, sodium galacturonate, sodium D-gluconate. 
Table 3. Major characteristics that distinguish Granulicella gen. nov. and related genera

Data for the related genera were taken from the following sources: Eichorst et al. (2007) (Terriglobus), Koch et al. (2008) (Edaphobacter) and Kishimoto et al. (1991) (Acidobacterium). ND, Not determined.

\begin{tabular}{|c|c|c|c|c|}
\hline Characteristic & Granulicella & Terriglobus & Edaphobacter & Acidobacterium \\
\hline Source of isolation & $\begin{array}{c}\text { Species of Sphagnum peat } \\
\text { and Cladonia }\end{array}$ & Soil and termite hindgut & Alpine and forest soil & $\begin{array}{c}\text { Acidic mineral } \\
\text { environment }\end{array}$ \\
\hline Motility & - & - & $+^{\star}$ & + \\
\hline Copious EPS production & + & + & - & - \\
\hline Pigment & Pink to red & Pink or none & None & Orange \\
\hline pH optimum & $3.8-4.5$ & $5.0-6.0$ & 5.5 & ND \\
\hline \multicolumn{5}{|l|}{ Growth at/in: } \\
\hline $\mathrm{pH}<4$ & + & - & - & + \\
\hline $3.5 \% \mathrm{NaCl}$ & + & - & - & - \\
\hline $37^{\circ} \mathrm{C}$ & - & - & + & + \\
\hline $4{ }^{\circ} \mathrm{C}$ & + & - & - & ND \\
\hline DNA G $+\mathrm{C}$ content $(\mathrm{mol} \%)$ & $57.3-59.3$ & $58.1-59.8$ & $55.8-56.9$ & $59.9-60.8$ \\
\hline
\end{tabular}

${ }^{\star}$ Only for strain Jbg- $1^{\mathrm{T}}$ (Koch et al., 2008).

Unable to utilize D-arabinose, D-sorbose, D-fucose, D-ribose, trehalose, mannitol, sorbitol, dulcitol, acetate, pyruvate, malate, lactate, succinate, butyrate, oxalate, propionate, formate, fumarate, capronate, citrate, valerate, adonitol, ethanol or methanol. Variable utilization of D-xylose, glucuronate, myo-inositol, arbutin and inulin. Hydrolyses aesculin, laminarin, pectin, lichenan, starch and xylan but not sodium alginate, CM-cellulose, cellulose, chitin, chitosan, fucoidan or pullulan. The following enzyme activities are present: valine arylamidase, $\alpha$-glucosidase, $N$-acetyl- $\beta$ glucosaminidase. Activities of urease, trypsin and esterase (C8) are absent. Esterase (C4) and $\alpha$-chymotrypsin activities are variable (API ZYM test). Oxidase- and catalase-positive. Capable of growth at $\mathrm{pH} 3.0-7.5$ (optimum $\mathrm{pH} 4.2$ ) and at 2-33 ${ }^{\circ} \mathrm{C}$ (optimum $18-22{ }^{\circ} \mathrm{C}$ ). Resistant to ampicillin, kanamycin, chloramphenicol, gentamicin, streptomycin and neomycin but susceptible to lincomycin and novobiocin.

The type strain OB1010 ${ }^{\mathrm{T}}\left(=\mathrm{DSM} 22464^{\mathrm{T}}=\mathrm{LMG} 25275^{\mathrm{T}}\right.$ ) was isolated from the Sphagnum peat bog Obukhovskoe, Yaroslavl region, European North Russia.

\section{Description of Granulicella rosea sp. nov.}

Granulicella rosea (ro'se.a. L. fem. adj. rosea rose-coloured).

The description is as for the genus but with the following additional traits. Cells are $0.5-1.0 \times 1.5-9.0 \mu \mathrm{m}$. Colony colour varies from pale pink to pink. Produces copious amounts of EPS. Growth is non-homogeneous in liquid medium. Able to utilize the following carbon sources
$(0.05 \%$, w/v): D-glucose, D-fructose, maltose, D-xylose, sodium D-galacturonate, glucuronate, pyruvate, malate and salicin. Unable to utilize D-arabinose, sucrose, D-galactose, lactose, lactulose, leucrose, D-mannose, melibiose, melezitose, raffinose, D-rhamnose, D-ribose, D-sorbose, trehalose, D-fucose, cellobiose, $\mathrm{N}$-acetylglucosamine, adonitol, mannitol, myo-inositol, sorbitol, dulcitol, arbutin, inulin, acetate, gluconate, lactate, succinate, butyrate, oxalate, propionate, formiate, fumarate, capronate, citrate, valerate, ethanol or methanol. Hydrolyses aesculin, laminarin, pectin, lichenan, starch and xylan but not sodium alginate, CM-cellulose, cellulose, chitin, chitosan, fucoidan or pullulan. Esterase (C8) is present. The following enzyme activities are absent: valine arylamidase, $\alpha$-glucosidase, $N$-acetyl- $\beta$-glucosaminidase, esterase (C4), urease and $\alpha$-chymotrypsin (API ZYM test). Oxidase-negative. Catalase-positive. Capable of growth at $\mathrm{pH}$ 3.0-7.5 (optimum $\mathrm{pH} 4.5$ ) and at 2-33 ${ }^{\circ} \mathrm{C}$ (optimum 18-22 $\left.{ }^{\circ} \mathrm{C}\right)$. Resistant to chloramphenicol, gentamicin, streptomycin, neomycin, lincomycin and novobiocin but susceptible to ampicillin and kanamycin.

The type strain TPO $1014^{\mathrm{T}}\left(=\mathrm{DSM} 18704^{\mathrm{T}}=\right.$ ATCC BAA$1396^{\mathrm{T}}$ ) was isolated from the Sphagnum peat bog Obukhovskoe, Yaroslavl region, European North Russia.

Description of Granulicella pectinivorans sp. nov.

Granulicella pectinivorans (pec.ti.ni.vor'ans. N.L. n. pectinum pectin; L. part. adj. vorans devouring; N.L. part. adj. pectinivorans pectin-devouring, referring to the ability to use pectin as a growth substrate). 
The description is as for the genus but with the following additional traits. Cells are $0.8-1.0 \times 1.5-15 \mu \mathrm{m}$. Colony colour varies from pale pink to red. Produces copious amounts of EPS. Able to utilize the following carbon sources $(0.05 \%, \mathrm{w} / \mathrm{v})$ : D-glucose, D-fructose, D-galactose, D-mannose, melibiose, D-xylose, cellobiose, sucrose, trehalose, $N$-acetyl-Dglucosamine, acetate, gluconate, lactate, sodium D-galacturonate, succinate, mannitol, inulin and myo-inositol. Unable to utilize D-arabinose, lactose, lactulose, leucrose, maltose, melezitose, raffinose, D-rhamnose, D-ribose, D-sorbose, Dfucose, salicin, arbutin, adonitol, sorbitol, dulcitol, glucuronate, malate, pyruvate, butyrate, oxalate, propionate, formiate, fumarate, capronate, citrate, valerate, ethanol or methanol. Hydrolyses aesculin, laminarin, pectin, lichenan, starch and xylan but not sodium alginate, CM-cellulose, cellulose, chitin, chitosan, fucoidan or pullulan. The following enzyme activities are present: valine arylamidase, $\alpha$-glucosidase, $N$-acetyl- $\beta$-glucosaminidase, esterase, urease and $\alpha$-chymotrypsin (API ZYM test). Oxidase-positive. Capable of growth at $\mathrm{pH} 3.0-7.5$ (optimum $\mathrm{pH} 3.8-4.5$ ) and at $2-33{ }^{\circ} \mathrm{C}$ (optimum $18-22{ }^{\circ} \mathrm{C}$ ). Resistant to ampicillin, chloramphenicol, gentamicin, streptomycin and neomycin but susceptible to lincomycin, novobiocin and kanamycin.

The type strain TPB $6011^{\mathrm{T}}\left(=\mathrm{VKM} \mathrm{B}-2509^{\mathrm{T}}=\mathrm{DSM} 21001^{\mathrm{T}}\right)$ was isolated from the Sphagnum peat bog Bakchar, Tomsk region, West Siberia.

\section{Description of Granulicella aggregans sp. nov.}

Granulicella aggregans (ag'gre.gans. L. part. adj. aggregans from L. v. aggrego attaching one's self to, adhering to, referring to the ability of the cells to form aggregates).

The description is as for the genus but with the following additional traits. Cells are $0.8-1.5 \times 1.5-10 \mu \mathrm{m}$. Colony colour varies from pale pink to reddish pink. Produces copious amounts of EPS. Growth is non-homogeneous in liquid medium. Able to utilize the following carbon sources $(0.05 \%, \mathrm{w} / \mathrm{v})$ : D-glucose, D-fructose, D-galactose, lactulose, leucrose, maltose, D-mannose, D-rhamnose, D-ribose, Dxylose, sucrose, salicin, $\mathrm{N}$-acetyl-D-glucosamine, sodium Dgalacturonate, gluconate, glucuronate, malate, pyruvate, arabitol, arbutin, dulcitol, mannitol, myo-inositol and sorbitol. Unable to utilize D-arabinose, lactose, melibiose, melezitose, raffinose, D-sorbose, trehalose, D-fucose, cellobiose, acetate, butyrate, capronate, citrate, valerate, lactate, oxalate, propionate, succinate, formiate, fumarate, adonitol, inulin, methanol or ethanol. Hydrolyses aesculin, laminarin, pectin, lichenan, starch and xylan but not sodium alginate, CM-cellulose, cellulose, chitin, chitosan, fucoidan or pullulan. The following enzyme activities are present: esterase, valine arylaminidase, $\alpha$-chymotrypsin, $\alpha$-glucosidase, $N$ acetyl- $\beta$-glucosaminidase. The following enzyme activities are absent: $\alpha$-galactosidase, trypsin and urease (API ZYM test). Oxidase-negative. Catalase-positive. Capable of growth at $\mathrm{pH} 3.0-7.5$ (optimum $\mathrm{pH} 4.5$ ) and at $2-33{ }^{\circ} \mathrm{C}$ (optimum $\left.18-22{ }^{\circ} \mathrm{C}\right)$. Resistant to chloramphenicol, gentamicin, streptomycin, neomycin, lincomycin, ampicillin and kanamycin but susceptible to novobiocin.

The type strain $\mathrm{TPB}^{2} 28^{\mathrm{T}}$ (=LMG $25274^{\mathrm{T}}=\mathrm{VKM}$ B$2571^{\mathrm{T}}$ ) was isolated from the Sphagnum peat bog Bakchar, Tomsk region, West Siberia.

\section{Acknowledgements}

This research was supported by the Molecular and Cell Biology and Biodiversity programs of the Russian Academy of Sciences, the RosNauka (project no. 02.740.11.0023), and the Russian Fund of Basic Research (grant no. 09-04-00004). The authors thank N. E. Suzina for electron microscopy and E. N. Detkova for the DNA G + C content and DNA-DNA hybridization analyses.

\section{References}

Barns, S. M., Takala, S. L. \& Kuske, C. R. (1999). Wide distribution and diversity of members of the bacterial kingdom Acidobacterium in the environment. Appl Environ Microbiol 65, 1731-1737.

Barns, S. M., Cain, E. C., Sommerville, L. \& Kuske, C. R. (2007). Acidobacteria phylum sequences in uranium-contaminated subsurface sediments greatly expand the known diversity within the phylum. Appl Environ Microbiol 73, 3113-3116.

Bryant, D. A., Costas, A. M., Maresca, J. A., Chew, A. G., Klatt, C. G., Bateson, M. M., Tallon, L. J., Hostetler, J., Nelson, W. C. \& other authors (2007). Candidatus Chloracidobacterium thermophilum: an aerobic phototrophic acidobacterium. Science 317, 523-526.

Coates, J. D., Ellis, D. J., Gaw, C. V. \& Lovley, D. R. (1999). Geothrix fermentans gen. nov., sp. nov., a novel Fe(III)-reducing bacterium from a hydrocarbon-contaminated aquifer. Int J Syst Bacteriol 49, 1615-1622.

De Ley, J., Cattoir, K. \& Reynaerts, A. (1970). The quantitative measurement of DNA hybridization from renaturation rates. Eur $J$ Biochem 12, 133-142.

Dedysh, S. N., Pankratov, T. A., Kulichevskaya, I. S., Belova, S. E. \& Liesack, W. (2006). Phylogenetic analysis and in situ identification of bacteria community composition in an acidic Sphagnum peat bog. Appl Environ Microbiol 72, 2110-2117.

Eichorst, S. A., Breznak, J. A. \& Schmidt, T. M. (2007). Isolation and characterization of soil bacteria that define Terriglobus gen. nov., in the phylum Acidobacteria. Appl Environ Microbiol 73, 2708-2717.

Felsenstein, J. (1989). PHYLIP - phylogeny inference package (version 3.2). Cladistics 5, 164-166.

Fukunaga, Y., Kurahashi, M., Yanagi, K., Yokota, A. \& Harayama, Sh. (2008). Acanthopleuribacter pedis gen. nov., sp. nov., a marine bacterium isolated from a chiton, and description of Acanthopleuribacteraceae fam. nov., Acanthopleuribacterales ord. nov., Holophagaceae fam. nov., Holophagales ord. nov. and Holophagae classis nov. in the phylum 'Acidobacteria'. Int J Syst Evol Microbiol 58, 2597-2601.

Gerhardt, P., Murray, R. G. E., Costilow, R. N., Nester, E. W., Wood, W. A., Krieg, N. R. \& Phillips, G. B. (editors) (1981). Manual of Methods for General Bacteriology. Washington, DC: American Society for Microbiology.

Hugenholtz, P., Pitulle, C., Hershberger, K. L. \& Pace, N. R. (1998). Novel division level bacterial diversity in a Yellowstone hot spring. J Bacteriol 180, 366-376.

Janssen, P. H. (2006). Identifying the dominant soil bacterial taxa in libraries of $16 \mathrm{~S}$ rRNA and 16S rRNA genes. Appl Environ Microbiol 72, 1719-1728. 
Kämpfer, P. \& Kroppenstedt, R. M. (1996). Numerical analysis of fatty acid patterns of coryneform bacteria and related taxa. Can $J$ Microbiol 42, 989-1005.

Kishimoto, N., Kosako, Y. \& Tano, T. (1991). Acidobacterium capsulatum gen. nov., sp. nov.: an acidophilic chemoorganotrophic bacterium containing menaquinone from acidic mineral environment. Curr Microbiol 22, 1-7.

Kleinsteuber, S., Müller, F.-D., Chatzinotas, A., Wendt-Potthoff, K. \& Harms, H. (2008). Diversity and in situ quantification of Acidobacteria subdivision 1 in an acidic mining lake. FEMS Microbiol Ecol 63, 107-117.

Koch, I. H., Gich, F., Dunfield, P. F. \& Overmann, J. (2008). Edaphobacter modestus gen. nov., sp. nov., and Edaphobacter aggregans sp. nov., acidobacteria isolated from alpine and forest soils. Int J Syst Evol Microbiol 58, 1114-1122.

Kulichevskaya, I. S., Suzina, N. E., Liesack, W. \& Dedysh, S. N. (2010). Bryobacter aggregatus gen. nov., sp. nov., a peat-inhabiting, aerobic chemo-organotroph from subdivision 3 of the Acidobacteria. Int J Syst Evol Microbiol 60, 301-306.

Lauber, C. L., Hamady, M., Knight, R. \& Fierer, N. (2009). Pyrosequencing-based assessment of soil $\mathrm{pH}$ as a predictor of soil bacterial community structure at the continental scale. Appl Environ Microbiol 75, 5111-5120.

Liesack, W., Bak, F., Kreft, J. U. \& Stackebrandt, E. (1994). Holophaga foetida gen. nov., sp. nov., a new homoacetogenic bacterium degrading methoxylated aromatic compounds. Arch Microbiol 162, 85-90.

Ludwig, W., Strunk, O., Westram, R., Richter, L., Meier, H., Yadhukumar, Buchner, A., Lai, T., Steppi, S. \& other authors (2004). ARB: a software environment for sequence data. Nucleic Acids Res 32, 1363-1371.

Luft, J. H. (1964). Electron microscopy of cell extraneous coats as revealed by ruthenium red staining. J Cell Biol 23, 54A-55A.

Martiny, A. C., Albrechtsen, H.-J., Arvin, E. \& Molin, S. (2005). Identification of bacteria in biofilm and bulk water samples from a nonchlorinated model drinking water distribution system: detection of a large nitriteoxidizing population associated with Nitrospira spp. Appl Environ Microbiol 71, 8611-8617.

Meisinger, D. B., Zimmermann, J., Ludwig, W., Schleifer, K.-H., Wanner, G., Schmid, M., Bennett, P. C., Engel, A. S. \& Lee, N. M.
(2007). In situ detection of novel Acidobacteria in microbial mats from a chemolithoautotrophically based cave ecosystem (Lower Kane Cave, WY, USA). Environ Microbiol 9, 1523-1534.

Owen, R. J., Lapage, S. P. \& Hill, L. R. (1969). Determination of base composition from melting profiles in dilute buffers. Biopolymers 7 , 503-516.

Pankratov, T. A., Tindall, B. J., Liesack, W. \& Dedysh, S. N. (2007). Mucilaginibacter paludis gen. nov., sp. nov. and Mucilaginibacter gracilis sp. nov., pectin-, xylan- and laminarin-degrading members of the family Sphingobacteriaceae from acidic Sphagnum peat bog. Int J Syst Evol Microbiol 57, 2349-2354.

Pankratov, T. A., Serkebaeva, Y. M., Kulichevskaya, I. S., Liesack, W. \& Dedysh, S. N. (2008). Substrate-induced growth and isolation of Acidobacteria from acidic Sphagnum peat. ISME J 2, 551-560.

Pansu, M. \& Gautheyrou, J. (2006). Handbook of Soil Analysis. Berlin, Heidelberg: Springer.

Reichardt, W. \& Morita, R. Y. (1982). Survival stages of a psychrotrophic Cytophaga johnsonae strain. Can J Microbiol 28, 841-850.

Reichenbach, H. (2006). The order Cytophagales. In The Prokaryotes: a Handbook on the Biology of Bacteria, 3rd edn, vol. 7, pp. 549-590. Edited by M. Dworkin, S. Falkow, E. Rosenberg, K. H. Schleifer \& E. Stackebrandt. New York: Springer.

Reynolds, E. S. (1963). The use of lead citrate at high $\mathrm{pH}$ as an electron opaque stain in electron microscopy. J Cell Biol 17, 208-212.

Scott, J. E., Quintaretti, G. \& Dellovo, M. C. (1964). The chemical and histochemical properties of alcian blue. I. The mechanisms of alcian blue staining. Histochemie 4, 73-85.

Ward, N. L., Challacombe, J. F., Janssen, P. H., Henrissat, B., Coutinho, P. M., Wu, M., Xie, G., Haft, D. H., Sait, M. \& other authors (2009). Three genomes from the phylum Acidobacteria provide insight into their lifestyles in soils. Appl Environ Microbiol 75, 20462056.

Zimmermann, J., Gonzalez, J. M., Saiz-Jimenez, C. \& Ludwig, W. (2005). Detection and phylogenetic relationships of highly diverse uncultured acidobacterial communities in Altamira Cave using $23 \mathrm{~S}$ rRNA sequence analysis. Geomicrobiol J 22, 379-388. 